Thorax, 1977, 32, 19-25

\title{
Tumour size as a prognostic factor after resection of lung carcinoma
}

\author{
A. S. SOORAE AND R. ABBEY SMITH \\ From the Cardio-Thoracic Unit, Walsgrave Hospital, Clifford Bridge Road, Coventry CV2 2DX
}

\begin{abstract}
Soorae, A. S. and Abbey Smith, R. (1977). Thorax, 32, 19-25. Tumour size as a prognostic factor after resection of lung carcinoma. Two hundred and ninety-five patients who underwent resection for carcinoma of the lung are reviewed, with a particular view to size of tumour and survival rate. The carcinomas were divided into four groups by size. It was found that the larger the tumour the worse was the prognosis. The prognosis in large carcinomas could not be directly attributed to a preponderance of an unfavourable cell type, lymph node metastasis or mediastinal extension. Vascular dissemination at the time of operation is believed to be a major factor for the poor prognosis in this group of carcinomas. Radiotherapy before operation and early ligation of the pulmonary veins might improve the results of resection of large carcinomas.
\end{abstract}

Various studies have laid different emphasis on prognostic factors which influence survival after resection of lung carcinoma. A relationship between the size of carcinoma and survival is not established. Wellons et al. (1968) report a definite relation between tumour size and survival, with a poor prognosis in cancers more than $5 \mathrm{~cm}$ in diameter. Yashar and Yashar (1975) reported no long-term survivors after resection of lesions larger than $7 \mathrm{~cm}$ in diameter. Slack (1970) reported a considerable reduction in five-year survival as tumour size increased. However, Rienhoff et al. (1965) and Adams (1948) found no relationship between carcinoma size and long-term survival. Shields et al. (1972) considered that size should influence survival but were unable to confirm this.

Our study was prompted by the fact that there were no 10-year survivors after resection of carcinomas of $7 \mathrm{~cm}$ or more in diameter in patients who underwent resection before 1966 . Carcinomas of $7 \mathrm{~cm}$ or more in greater diameter will be referred to as large carcinomas in this paper.

In the 10-year survivors such unfavourable prognostic features as oat cell carcinoma, mediastinal node involvement, microscopic blood vessel invasion in the resected specimen, and an extended type of operation (Chamberlain et al., 1959) were features in a number of cases (Abbey Smith, 1970).

We attempt to clarify the prognostic significance of the size of resectable carcinomas by means of a prospective study of a relatively small number of patients, and suggest a different approach to resection in large carcinomas. When the lesion exceeds $7 \mathrm{~cm}$ in diameter the survival rate after resection is uniformly dismal, and in our view a size of $7 \mathrm{~cm}$ or more is one of the worst prognostic features in carcinomas that are resectable. In this study $77.6 \%$ of patients had died within one year after undergoing resection of large carcinomas. An equally bad prognosis after resection is found when the carcinoma produces ectopic hormone.

\section{Material and methods}

A total of 295 consecutive patients underwent resection for primary carcinoma of the lung between October 1969 and June 1974. The size of the carcinoma and the length of survival after resection were studied prospectively and the results were analysed in July 1976. The numbers and types of resection are shown in Table 1 . The resectability rate was $98 \%$. Involvement of mediastinal nodes and adjacent structures such as diaphragm, chest wall or pericardium were not 
Table 1 Number and types of resection

\begin{tabular}{lcc}
\hline Type of resection & Number & Percentage \\
\hline Pneumonectomy & 142 & $48 \cdot 1$ \\
Lobectomy & 132 & $44 \cdot 8$ \\
Sleeve resection & 11 & $3 \cdot 7$ \\
Segmental resection & 10 & $3 \cdot 4$ \\
Total & 295 & \\
\hline
\end{tabular}

necessarily regarded as contraindications to resection. All large carcinomas explored were resected. No radiotherapy or cytotoxic drugs were given before or after resection. No macroscopically visible residual mediastinal carcinoma remained at the conclusion of the resection of any large carcinoma. Technical difficulties were not as great as anticipated.

The tumour was measured along its maximum diameter in the uninflated lung or lobe after resection. The size was confirmed by measurement of the shadow in the chest radiograph. All large carcinomas were approximately spherical. No attempt was made to measure tumour volume. The largest resected carcinoma measured $21 \mathrm{~cm}$ in greatest diameter and weighed $2.78 \mathrm{~kg}$.

The 295 carcinomas were divided into four groups: A, less than $3.0 \mathrm{~cm}$; B, $3.0 \mathrm{~cm}$ to $4.9 \mathrm{~cm}$; C, $5.0 \mathrm{~cm}$ to $6.9 \mathrm{~cm}$; and $\mathrm{D}, 7.0 \mathrm{~cm}$ and more.

There were 67 carcinomas in group D (large carcinoma) with a mean diameter of 8.4 (range 7-21) $\mathrm{cm}$.

The patients' ages in the 295 resections varied from 35 to 75 years with a mean of $57 \cdot 3$ years. The mean age of patients with large carcinomas was 54.5 years. There were 261 males with a male to female ratio of $7 \cdot 4: 1$.

\section{Results}

Nineteen $(6.4 \%)$ of the 295 patients died in hospi- tal after resection; 10 of these patients died fron pulmonary embolism. Six $(8.9 \%)$ of the 67 patient with large carcinomas died in hospital after res section and underwent necropsy. Two died fron 8 pulmonary embolism, one from haemorrhagen one from pericarditis, one from the results of a bronchopleural fistula, and in one the cause of death was undetermined. In none of the six patients who died in hospital was there any evio dence at necropsy of metastasis in distant organs

In addition to the details of cell type (Table $2 \phi^{2}$ the possibility of lymph node involvement in each resected specimen was looked into. Size and sur $\overrightarrow{0}$ vival rates are analysed (Table 3 ). Table 4 contains an analysis of size, histology, and extent of lymph? node involvement. In large carcinomas $95.5 \%$ of patients died within 30 months. All deaths, except $\frac{\mathbb{O}}{8}$ ing hospital deaths $(8.9 \%)$, were a direct result of vascular dissemination of carcinoma. Only three patients survived more than 30 months after re

Table 2 Histology in 295 carcinomas

\begin{tabular}{lcc}
\hline Cell type & Number & Percentage \\
\hline Squamous cell & 160 & $54 \cdot 2$ \\
Anaplastic & 81 & $27 \cdot 5$ \\
Oat cell & 29 & $9 \cdot 8$ \\
Adenocarcinoma & 19 & $6 \cdot 5$ \\
Miscellaneous & 6 & $2 \cdot 0$ \\
\hline
\end{tabular}

Table 3 Size of carcinoma and survival in 295 patients

\begin{tabular}{|c|c|c|c|c|}
\hline $\begin{array}{l}\text { Size of } \\
\text { carcinoma } \\
(\mathrm{cm})\end{array}$ & $\begin{array}{l}\text { Total } \\
\text { number of } \\
\text { patients }\end{array}$ & $\begin{array}{l}\text { Percentage } \\
\text { of } \\
\text { patients }\end{array}$ & $\begin{array}{l}\text { Number } \\
\text { surviving } \\
\text { two or more } \\
\text { years }\end{array}$ & $\begin{array}{l}\text { Percentage } \\
\text { survival }\end{array}$ \\
\hline $\begin{array}{l}\text { Less than } 3 \\
3 \cdot 0-4 \cdot 9 \\
5 \cdot 0-6 \cdot 9 \\
7 \text { and more }\end{array}$ & $\begin{array}{r}55 \\
101 \\
72 \\
67\end{array}$ & $\begin{array}{l}18 \cdot 7 \\
34 \cdot 2 \\
24 \cdot 4 \\
22 \cdot 7\end{array}$ & $\begin{array}{r}33 \\
36 \\
13 \\
3\end{array}$ & $\begin{array}{r}60 \cdot 0 \\
35 \cdot 6 \\
18 \cdot 0 \\
4 \cdot 5\end{array}$ \\
\hline
\end{tabular}

Table 4 Analysis of size, histology, and hilar nodes in 295 patients

\begin{tabular}{|c|c|c|c|c|c|c|c|c|}
\hline \multirow{2}{*}{$\begin{array}{l}\text { Nodes and } \\
\text { size of tumour }\end{array}$} & \multicolumn{5}{|l|}{ Histology } & \multirow{2}{*}{$\begin{array}{l}\text { Number } \\
\text { of } \\
\text { patients }\end{array}$} & \multicolumn{2}{|c|}{ Positive nodes } \\
\hline & Squamous & Anaplastic & Oat cell & Adeno & Miscellaneous & & Number & Percent \\
\hline $\begin{array}{l}\text { Less than } 3 \mathrm{~cm} \\
\text { Positive nodes }\end{array}$ & $\begin{array}{r}31 \\
9\end{array}$ & $\begin{array}{l}16 \\
12\end{array}$ & $\begin{array}{l}3 \\
1\end{array}$ & $\begin{array}{l}3 \\
1\end{array}$ & $\underline{2}$ & 55 & 23 & $41 \cdot 8$ \\
\hline $\begin{array}{l}3.0-4.9 \mathrm{~cm} \\
\text { Positive nodes }\end{array}$ & $\begin{array}{l}61 \\
29\end{array}$ & $\begin{array}{l}24 \\
15\end{array}$ & $\begin{array}{l}6 \\
4\end{array}$ & $\begin{array}{l}5 \\
2\end{array}$ & $\begin{array}{l}4 \\
2\end{array}$ & 101 & 52 & $51 \cdot 5$ \\
\hline $\begin{array}{l}5 \cdot 0-6.9 \mathrm{~cm} \\
\text { Positive nodes }\end{array}$ & $\begin{array}{l}31 \\
17\end{array}$ & $\begin{array}{r}24 \\
9\end{array}$ & $\begin{array}{l}12 \\
11\end{array}$ & $\begin{array}{l}5 \\
4\end{array}$ & - & 72 & 41 & $56 \cdot 2$ \\
\hline $\begin{array}{l}7.0 \mathrm{~cm} \text { and mole } \\
\text { Positive nodes }\end{array}$ & $\begin{array}{l}37 \\
18\end{array}$ & $\begin{array}{r}16 \\
7\end{array}$ & $\begin{array}{l}8 \\
6\end{array}$ & $\begin{array}{l}6 \\
3\end{array}$ & - & 67 & 34 & $50 \cdot 7$ \\
\hline Total & & & & & & 295 & 150 & $50 \cdot 6$ \\
\hline
\end{tabular}


Table 5 Details of the three survivors-large carcinomas (group D)

\begin{tabular}{|c|c|c|c|c|c|c|c|c|c|}
\hline \multirow{2}{*}{ Patient } & \multirow{2}{*}{ Age } & \multirow{2}{*}{ Se.x } & \multirow{2}{*}{$\begin{array}{l}\text { Type of } \\
\text { resection }\end{array}$} & \multirow{2}{*}{$\begin{array}{l}\text { Date of } \\
\text { resection }\end{array}$} & \multirow{2}{*}{$\begin{array}{l}\text { Size of } \\
\text { carcinoma }\end{array}$} & \multirow{2}{*}{ Histology } & \multicolumn{2}{|l|}{ Nodes } & \multirow{2}{*}{ Postresection state } \\
\hline & & & & & & & Hilar & Other & \\
\hline IC & 63 & Female & $\begin{array}{l}\text { Right } \\
\text { pneumonectomy }\end{array}$ & 4 May 1971 & $12.0 \mathrm{~cm}$ & Squamous & $-\mathrm{ve}$ & - ve & $\begin{array}{l}\text { Excision of a solitary } \\
5 \cdot 5 \times 4 \mathrm{~cm} \text { metastatic } \\
\text { skin nodule from chest } \\
\text { wall on } 25 \text { February } 1972 \text {. } \\
\text { Now well and clinically } \\
\text { tumour-free in June } 1976\end{array}$ \\
\hline EL & 68 & Male & $\begin{array}{l}\text { Left } \\
\text { pneumonectomy }\end{array}$ & 30 Nov. 1971 & $7.0 \mathrm{~cm}$ & $\begin{array}{l}\text { Squamous poorly } \\
\text { differentiated }\end{array}$ & tve & $-\mathbf{v e}$ & $\begin{array}{l}\text { Well and clinically } \\
\text { tumour-free in June } 1976\end{array}$ \\
\hline EF & 70 & Male & $\begin{array}{l}\text { Left upper } \\
\text { lobectomy }^{1}\end{array}$ & 17 July 1973 & $7.0 \mathrm{~cm}$ & $\begin{array}{l}\text { Squamous poorly } \\
\text { differentiated }\end{array}$ & $+\mathrm{ve}$ & $-\mathrm{ve}$ & $\begin{array}{l}\text { Well and clinically } \\
\text { tumour-free in June } 1976\end{array}$ \\
\hline
\end{tabular}

'On extubation this patient developed cardiac arrest caused by tracheal obstruction due to a displaced portion of tumour. The tumour fragment was removed by bronchoscopy and a normal heart beat was restored.

section (Table 5 and Figs 1-3). During the period of this study two large metastatic neoplasms were resected by lobectomy (Figs 4 and 5). One patient who had a $10.0 \mathrm{~cm}$ metastasis from an adenocarcinoma of colon is apparently tumour-free four years after resection; the other who had a $9.0 \mathrm{~cm}$ infiltrating metastasis from an osteogenic sarcoma of the femur is also apparently tumour-free sixand-a-half years after resection.

\section{Discussion}

The present study confirms our belief (not universally accepted) that large carcinomas have a poor prognosis. This is not owing to the predominance of an unfavourable histological cell type (Table 6), for the percentage of incidence of this cell type is similar in each group of carcinomas (Table 2).

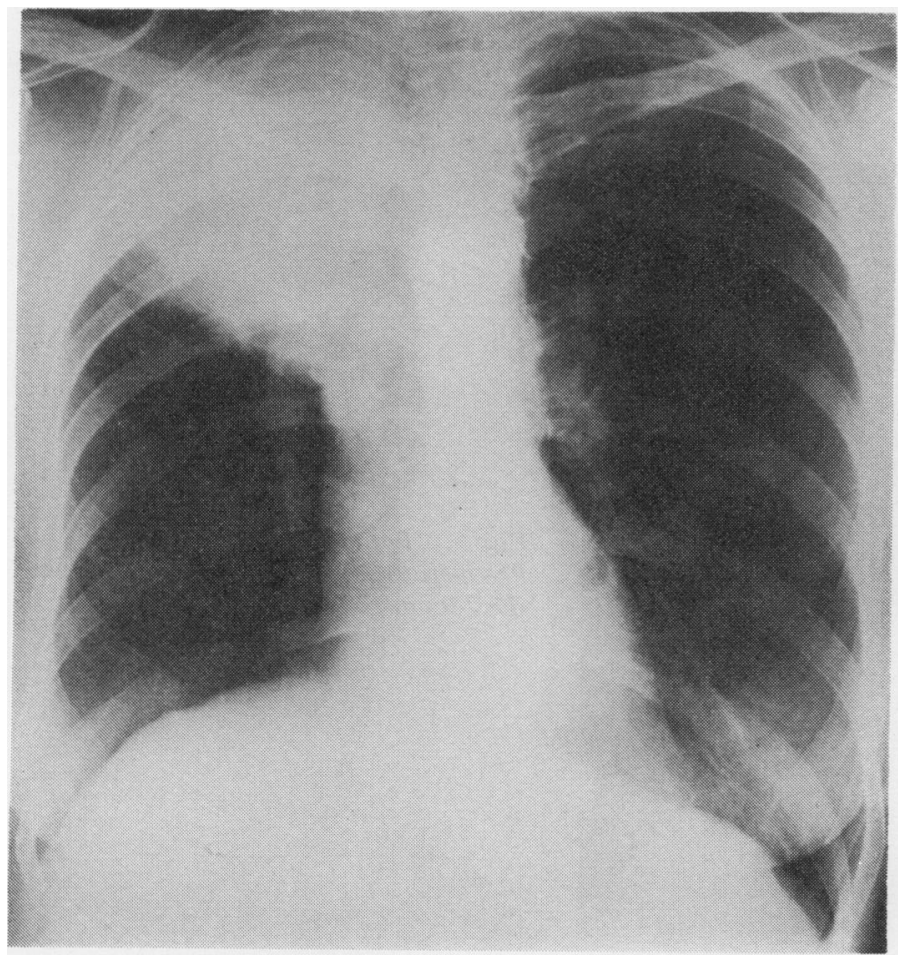

Fig. 1 (Patient IC, Table 5).

Preoperative chest radiograph showing the $12.0 \mathrm{~cm}$ carcinoma. 


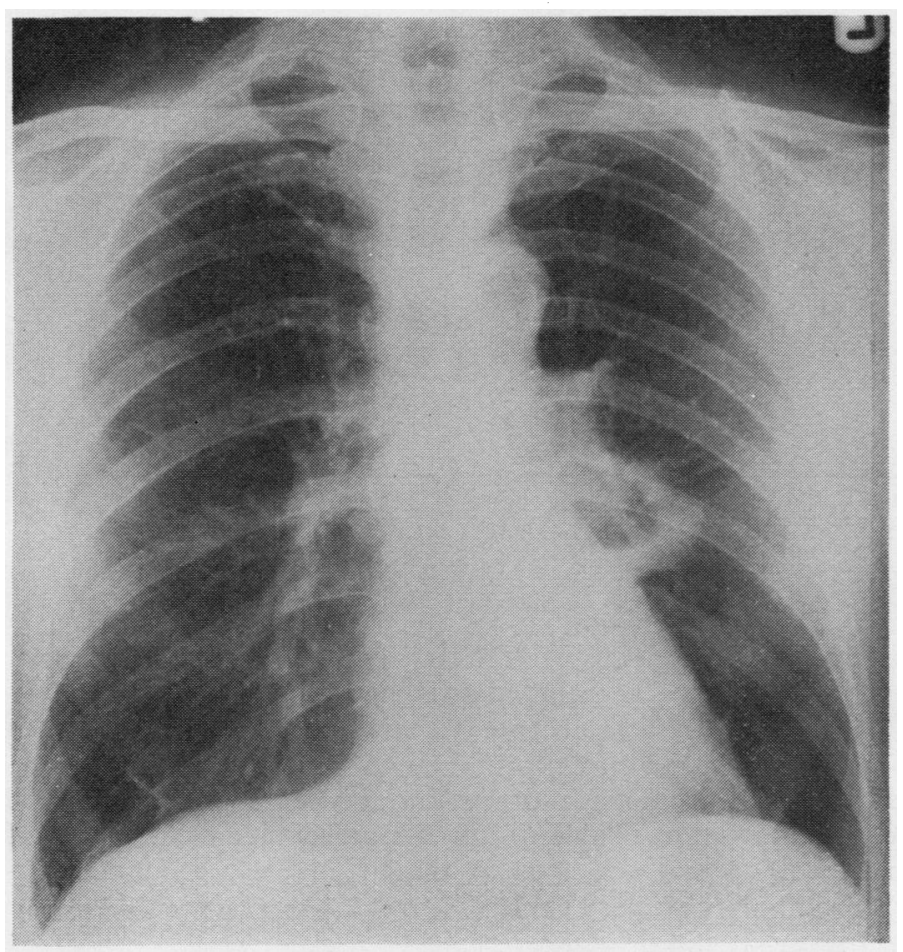

Fig. 2 (Patient EL, Table 5).

Preoperative chest radiograph showing

the $7.0 \mathrm{~cm}$ carcinoma.

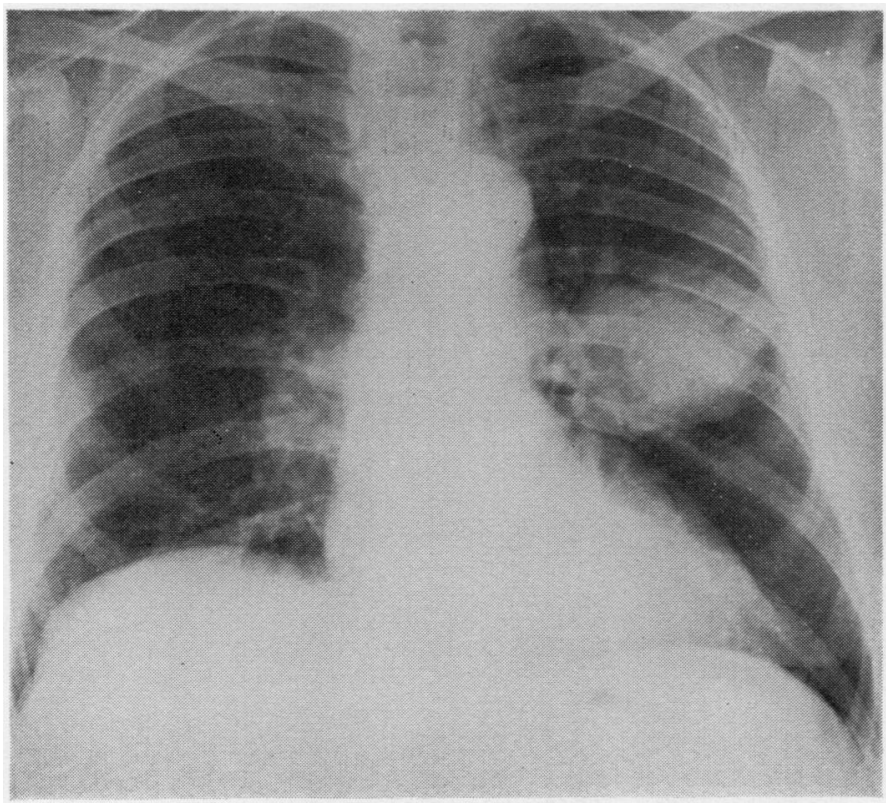

Fig. 3 (Patient EF, Table 5).

Preoperative chest radiograph showing the $7.0 \mathrm{~cm}$ carcinoma. 


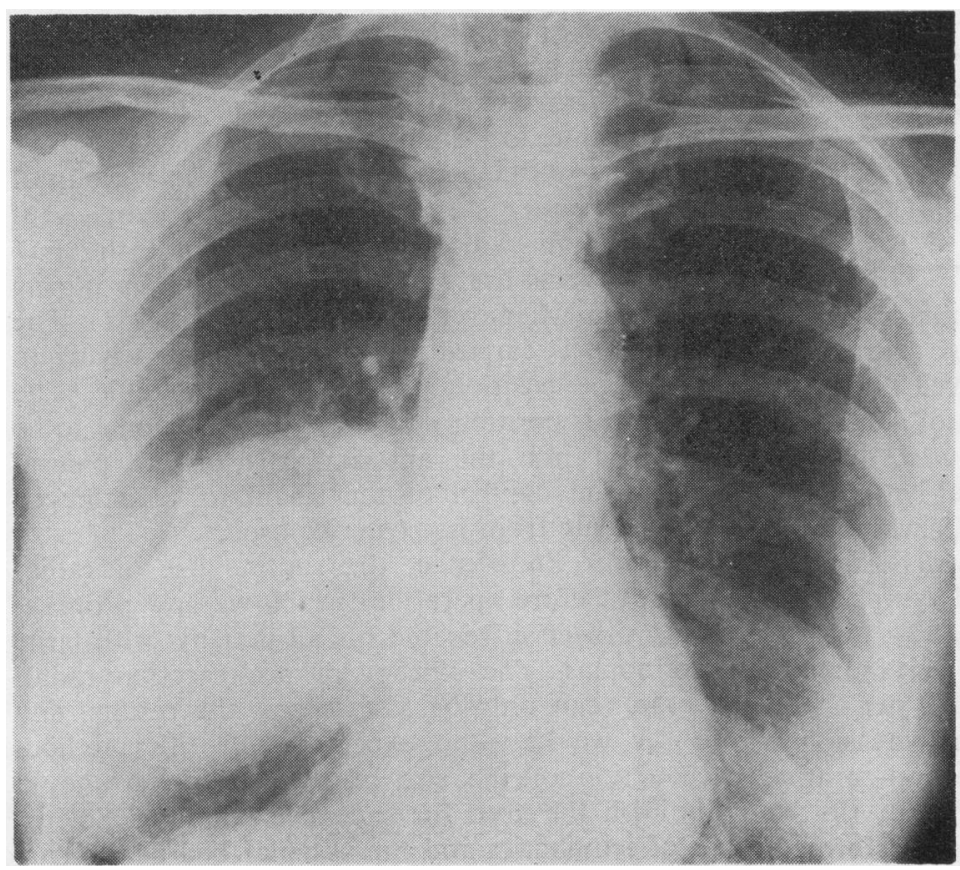

Fig. 4 Preoperative chest radiograph showing $10.0 \mathrm{~cm}$ metastasis from a carcinoma of colon resected seven years previously. Patient shows no evidence of further metastasis four years after resection of the metastasis by right lower lobectomy.

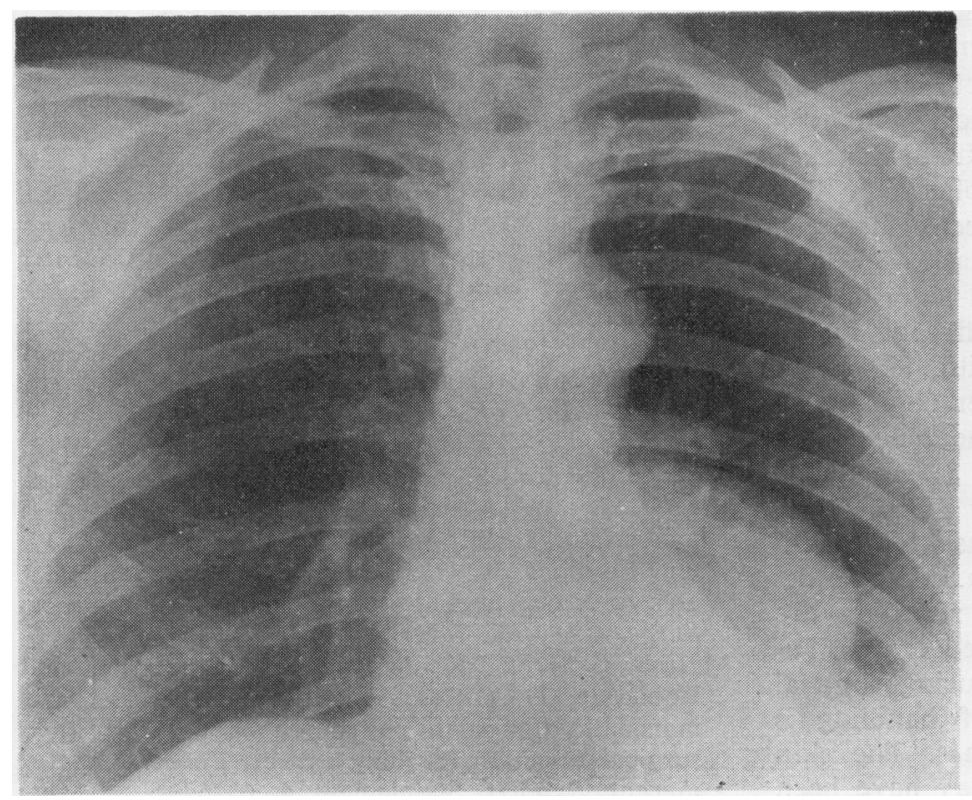

Fig. 5 Preoperative chest radiograph showing $9.0 \mathrm{~cm}$ metastasis from an osteogenic sarcoma of the knee amputated six years previously. Patient shows no evidence of further recurrence six-and-a-half years after resection of the metastasis by left lower lobectomy. 
Table 6 Histology in 67 large carcinomas

\begin{tabular}{lcc}
\hline Cell type & $\begin{array}{c}\text { No. of } \\
\text { patients }\end{array}$ & Percentage \\
\hline Squamous & 37 & 55.3 \\
Anaplastic & 16 & 23.9 \\
Oat cell & 8 & 11.9 \\
Adenocarcinoma & 6 & 8.9 \\
\hline
\end{tabular}

Of the 295 patients, $50.6 \%$ had hilar nodes involved by carcinoma. In the large carcinoma group, 50.7\% had hilar nodes involved (Table 4). The poor prognosis after resection of large carcinomas cannot be directly attributed to hilar lymph node involvement. Mediastinal lymph node invasion in large carcinomas $(16.4 \%)$ was similar to all groups combined $(15 \cdot 8 \%)$ which strongly suggests that hilar and mediastinal lymph node involvement at the time of resection is not the cause of the poor prognosis in large carcinomas.

Since most large carcinomas are peripheral (Walter and Pryce, 1955), mediastinal invasion is likely to be delayed. There were no non-curative resections (Chamberlain et al., 1959) in the 43 pneumonectomies and 24 lobectomies performed. No death occurred from mediastinal recurrence, so local recurrence does not contribute to the poor prognosis. The poor prognosis therefore is not directly related to cell type, hilar or mediastinal lymph node metastasis, or direct mediastinal invasion.

A factor which remains is blood vessel dissemination to distant organs. Deaths after leaving hospital in the large carcinoma group were a result of bloodborne metastasis, commonly to the brain, adrenals, kidneys, and liver. Pryce and Walter (1960) reported that invasion of arteries and veins is more common in peripheral tumours, and as large carcinomas are peripheral (Walter and Pryce, 1955), this may be indirect evidence to suggest that large carcinomas metastasize early. The incidence of undetected distal metastasis at the time of resection varies in different studies (Matthews et al., 1973; Abbey Smith, 1974). We have no evidence whatsoever, either clinically or from the hospital necropsies, that the incidence of distant metastasis before resection is greater in large carcinomas than in any other group. Every effort was made to exclude metastasis by a complete examination before operation. Most undetected metastases at the time of resection are small, single, and in a deeply placed organ. Tumour embolism may also occur during surgical manipulation as a fair amount of handling is necessary to resect large carcinomas. The skin metastasis (Patient IC, Table 5) may have been the result of a solitary tumour embolus dislodged $\stackrel{\vec{F}}{\stackrel{\rho}{\circ}}$ at the time of resection. Manipulation may also? dislodge fragments of tumour into the bronchial $\frac{\bar{\sigma}}{\mathrm{D}}$ tree causing obstruction (Patient EF, Table 5). $\frac{\text { क }}{\widetilde{\alpha}}$ We propose that, in the large carcinoma group of $\varrho$ patients, better survival rates may be achieved if के pre-resection radiotherapy is used and the pul- $\overrightarrow{0}$ monary veins are secured as the first step during operation whenever possible (Aylwin, 1951). The operation is carried out with the patient lying in the prone position on the operating table. The $x$ use of this position allows a large carcinoma to be displaced into the anterior part of the pleural. cavity and control of the hilum to be achieved $\overrightarrow{0}$ more easily from its posterior aspect.

To our knowledge, the routine use of radio- therapy before operation (which we now propose) ${ }_{\mathbb{Q}}^{\top}$ has not been advocated for all patients with large음 carcinomas. The efficacy of pre-resection radio-⿳亠丷⿵冂丶 therapy can only be assessed on the results, and ${ }^{2}$ so far we have no experience of this method. $\vec{\theta}$ Reduction of the size of the carcinoma should. $V$ diminish the need for excessive handling. Sclerosis of lymphatics and the vascular bed of the carcinoma might further limit dissemination. The unexpected long-term survival rate after resection of two large metastatic malignant tumours (Figs $4 \frac{2}{\Omega}$ and 5) is interesting. We have no explanations to offer for these patients' survival, although large 3 metastatic carcinomas in the lung would appear to have no worse a prognosis after resection thano do large primary lung carcinomas.

\section{References}

Abbey Smith, R. (1970). Long-term clinical follow-upg after operation for lung carcinoma. Thorax, 25; 62-76.

Abbey Smith, R. (1974). Pre-operative assessment techniques and results of surgery for bronchial caro cinoma. In Surgery of the Lung, The Coventry Conference, edited by R. E. Smith and W. Go Williams, pp. 3-17. Butterworths, London.

Adams, R. (1948). Carcinoma of the lung: factors affecting survival after resection of cancer of the lung. Journal of Thoracic Surgery, 17, 306-322. ㅇ

Aylwin, J. A. (1951). Avoidable vascular spread in resection for bronchial carcinoma. Thorax, 6 250-267.

Chamberlain, J. M., McNeill, T. M., Parnassa, P.导 and Edsall, J. R. (1959). Bronchogenic carcinoma? an aggressive surgical attitude. Journal of Thoracic Surgery, 38, 727-745.

Matthews, M. J., Kanhouwa, S., Pickren, J., and Robinette, D. (1973). Frequency of residual an metastatic tumor in patients undergoing curative surgical resection for lung cancer. Cancer Chemo therapy Reports, Supplement 4, 63-67. 
Pryce, D. M. and Walter, J. B. (1960). The frequency of gross vascular invasion in lung cancer with special reference to arterial invasion. Journal of Pathology and Bacteriology, 79, 141-146.

Rienhoff, W. F., Talbert, J. L., and Wood, S., Jr. (1965). Bronchogenic carcinoma: a study of cases treated at Johns Hopkins Hospital from 1933-1958. Annals of Surgery, 161, 674-684.

Shields, T. W., Higgins, G. A., and Keehn, R. J. (1972). Factors influencing survival after resection for bronchial carcinoma. Journal of Thoracic and Cardiovascular Surgery, 64, 391-399.

Slack, N. H. (1970). Bronchogenic carcinoma: nitrogen mustard as a surgical adjuvant and factors influencing survival. Cancer, 25, 987-1002.
Walter, J. B. and Pryce, D. M. (1955). The site of origin of lung cancer and its relation to histological type. Thorax, 10, 117-126.

Wellons, H. A., Jr., Johnson, G., Jr., Benson, W. R., Pate, D., Wilcox, B. R., and Peters, R. M. (1968). Prognostic factors in malignant tumours of the lung. Annals of Thoracic Surgery, 5, 228-235.

Yashar, J. and Yashar, J. J. (1975). Factors affecting long-term survival of patients with bronchogenic carcinoma. American Journal of Surgery, 129, 386-393.

Requests for reprints to: R. Abbey Smith, ChM, FRCS, Cardio-Thoracic Unit, Walsgrave Hospital, Clifford Bridge Road, Coventry CV2 2DX. 